\title{
24 \\ Developing Effective Guidelines for Faculty Teaching First-Year University Students
}

\author{
Irene Carter, Donald Leslie, \& Sarah Moore \\ University of Windsor
}

First-year university students are a diverse group of individuals with various abilities and needs. Failure of the university and its teaching faculty to meet the needs of first-year students may result in abandonment of the pursuit of a degree. This project informs instructors about the practices that strengthen a learning-centred approach and maximize inclusion of first-year students. The principles and teaching methods of Universal Instructional Design are learner-centred and have shown to improve academic achievement and benefit the campus community. Thus, it is suggested that the principles of this method be applied uniformly across university-level instruction.

\section{Introduction}

Cirst-year university students begin their post1 secondary education with various abilities and needs. Failure of the university and its teaching faculty to meet the needs of first-year students may result in abandonment of the pursuit of a degree. Improving the experiences of first-year students is crucial in retaining them to complete their degrees, and it is essential for faculty to become aware of how to address their needs. Having explored the literature on learning-centred teaching as well as the principles of teaching and Universal Instructional Design (UID), the authors propose a set of teaching strategies to help instructors of first-year students create an inclusive environment for students. These teaching strategies support the use of a learning-centred approach, the principles of teaching as well as UID in maximizing student success.

\section{Learner-Centred Approach}

Employing a learner-centred approach is an effective way of designing education so as to retain first-year students since it aims to support students by specifically targeting their needs. In contrast to traditional teaching methods where education is designed from the perspective of the instructor, a learner-centred approach aims chiefly to meet the student's learn- 
ing needs from the perspective of the students. Globally, colleges and universities are debating the value of implementing new student-centred learning perspectives, resulting in the increasing adoption of nontraditional methods and approaches by advanced learning institutions (Hubball, Gold, Mighty, \& Britnell, 2007).

Suggesting that a teacher-centred environment makes students uninterested in learning, Weimer (2002) writes that a learner-centred teaching environment allows faculty to "give students some control over those learning processes that directly affect them." Weimer explains that in learning-centred teaching, "teachers no longer function as exclusive content experts or authoritarian classroom managers" and that neither do they simply "work to improve teaching by developing sophisticated presentation skills" (p.14).

The learner-centred approach involves more than the pursuit of new techniques; it entails an integrated philosophy of education. Understanding the learning-centred approach to teaching requires an understanding of the role of power in the classroom. In a learning-centred environment, teachers do not one-sidedly make all the decisions about learning; rather they share these decisions with their students (Weimer, 2002). Weimer stresses that in UID, the instructor's primary goal is to teach students learning skills through setting clear expectations and presenting unambiguous instructions, thus enabling the students to teach themselves.

A learner-centred classroom does not cater to student whims in a manner that reduces academic rigor. Instead, it provides clear learning expectations, helps students in understanding and utilizing knowledge (Galka \& Gold, 2006), and fosters principles of accessibility and accommodation. Many universities support faculty in creating learner-centred classrooms through their teaching and learning centres and student disability services. Faculty also share first-year experiences with other faculty and collaborate on effectively producing and delivering first-year courses. However, faculty often face challenges in finding the time to attend teaching workshops or search websites for teaching tips on increasing accessibility and accommodation for first-year students. Also, the process of changing to a learner-centred approach must also involve assessing and analyzing one's own teaching methods and creating a plan for implementing an individual gradual change process (Weimer, 2002). Without help, instructors may fail to produce a classroom conducive to meeting students' needs for accessibility and for a successful transition into following years of study and on to graduation. Thus, focusing on the recent literature, the authors suggest a set of learner-centred teaching guidelines for faculty teaching first-year students.

\section{Principles for Good Practice in Education}

One important source of teaching guidelines is Chickering \& Gamson's Seven Principles for Good Practice in Undergraduate Education (1987). Many dedicated professors have incorporated these widely recognized, evidence-based teaching practices into their teaching methods. These principles include: 1) encouraging contact between students and faculty; 2) encouraging active listening; 3) stressing time on task; 4) providing prompt feedback; 5) communicating high expectations; 6) developing reciprocity and cooperation among students; and 7) respecting diverse talents and ways of learning. Although these principles do provide a set of teaching guidelines for first-year professors, because of their specific nature, they are not applicable to all areas of instruction. For example, these principles provide little insight into how to set up the physical space of the classroom, how to write an effective syllabus, or how to provide effective instruction for a diverse audience of students. Further, this relatively limited scope of application does not help instructors address student needs in a wide variety of educational situations. Therefore, to succeed in the task, faculty require a set of teaching practices with a wider scope of applicability.

\section{Principles of Universal Design}

The idea of universal design originally developed 
within the field of architecture. It aims to design products and environments that can be used by all people, to the greatest degree possible, and without the need for adaptation (Hebdon, 2007). For example, instead of creating a building to be used by the majority, as is the traditional practice, the principles of universal design suggest that buildings be designed to accommodate the greatest number and variety of individuals possible. Thus, architects using this method have aimed for flexible use by as many individuals as possible, regardless of handedness or motor dexterity, while rejecting the idea of simply making products for most users. The universal design perspective views people as individuals with varying abilities and preferences instead of seeing them as a homogeneous group.

Frank Bowe developed guidelines for applying the principles of universal design to teaching, highlighting "a few key instructional strategies" (Burgstahler, 2008). Applying the universal design perspective to education, termed Universal Design in Education, seeks to create educational processes, learning environments, and teaching strategies that are applicable to the greatest diversity of people possible (Samuels, 2007). This approach aims to develop an educational strategy that is suitable for as many people as possible, rather than an educational strategy designed for one learner. Sometimes, when applying these principles to college- and universitylevel education, the term Universal Design in Higher Education (UDHE) is used.

There are several dimensions to UDHE including physical spaces, information technology, services, and instruction - all of which allow for opportunities to adopt inclusive choices. Applying this perspective to teaching practices is one of the dimensions within Universal Design in Education. UID, also referred to as Universal Design for Instruction (UDI), involves universal design as it is applied to instructional products and environments (Burgstahler $\&$ Cory, 2008). This provides a set of principles for developing courses and teaching. The principles of UID recommend that instructors: 1) plan for equitable use; 2) plan for flexibility in use; 3) plan for simple and intuitive use; 4) plan for perceptible information; 5) plan for a tolerance for error built in;
6) plan for low physical effort; 7) plan to consider size and space for appropriate use; 8) plan to create a community of learners; and 9) plan to create an inclusive climate (Burgstahler \& Cory, 2008). Instructors who employ these principles in course design and delivery consider the potential needs of all learners, identifying and removing unnecessary barriers to teaching and learning, while preserving academic rigor (Burgstahler, \& Cory, 2008; Coomber, 2007). Not only is this learner-centred, but it is easy to carry out and applicable to the greatest number of learners possible.

\section{Benefits of UID Teaching Strategies}

The principles of UID (Burgstahler \& Cory, 2008) build on learner-centred perspectives and the Seven Principles for Good Practice in Undergraduate Education (Chickering \& Gamson, 1987), and provide faculty with guidelines that are applicable to all areas of education. When put into practice, these methods also produce benefits for academic success and for the school environment. Academically, implementing UID strategies improve the ability of students to concentrate, hold information, memorize information, understand, note-take, and achieve academic success (Mino, 2004; Yuval \& Korabik, 2003). When carrying out UID principles, these improvements occur without reducing academic rigor (Burgstahler, \& Cory, 2008). Therefore, student improvements are the outcome of greater teaching effectiveness resulting from these strategies and cannot be accounted for by reduced standards.

UID also produces many non-academic benefits that may help with retaining first-year students. UID practices affirm student diversity and promote a sense of community among students (Mino, 2004). This may aid universities in attracting and preserving a diverse cultural or ethnic student body (Embry, Parker, McGuire, \& Scott, 2005). Additionally, UID practices build inclusive practices into the educational process, normalizing student diversity and decreasing the need for specialized accommodations (Embry et al., 2005; Thousand, Villa, \& Nevin, 2002). 


\section{Challenges to Implementing Effective UID Teaching Strategies}

Despite the benefits outlined in the literature, UID is not uniformly adopted as the teaching standard by institutions of higher learning. The literature identified several barriers to carrying out these strategies. First, adopting a new teaching model needs leadership and administrative support (Embry et al., 2005). Without this support, it is difficult for faculty to receive training on UID, gain access to suitable facilities and technologies, or to redesign course curriculum. At times, universities may view UID strategies as being feasibly difficult to carry out because of recommendations that stress the need to incorporate technology into each classroom (Embry et al., 2005).

Second, individual faculty members often resist using UID. Faculty members hesitate to adopt a new approach when they lack training, experience, and expertise in UID (Embry et al., 2005). Where faculty fail to recognize the diversity that exists within university classrooms, they may not consider it necessary to adjust their approach (Embry et al., 2005). Finally, some faculty express concern that employing UID teaching practices will result in reduced control of the classroom environment for the instructor (Blizzard \& Foster, 2007).

Third, negative attitudes about accommodating various learners in higher education may act as a barrier to using UID. Adopting the UID perspective requires that one accept the position that accessibility issues exist within traditional teaching pedagogy, and that these affect learning of all students (Coomber, 2007). Coomber suggests that although faculty value UID practices, developing academic access for a diverse variety of students remains a challenge. Further, the UID teaching model is often inappropriately thought of as a method that focuses on individuals with disabilities rather than the entire student population (Finkel \& Gold, 1999). These attitudes towards diversity, accessibility, and disability have resulted in stalled efforts to using UID in the regular curriculum.

\section{UID Teaching Guidelines}

The nine principles of UID, many of which are familiar to effective teachers, provide an opportunity to develop teaching guidelines. When instructors apply UID to typical instructional areas, they create teaching guidelines. Faculty apply teaching guidelines, as summarized in the following areas (Carter, Leslie, \& Moore, 2009; Scott \& McGuire, 2008; Stolarchuk, Carter, \& Leslie, 2009):

\section{Classroom set-up}

- When teaching, present material that is visible to all students, whether seated or standing, and face students when speaking to them.

- Speak clearly, suitably pacing comments, and using variations in tone to highlight the information during discussion.

- Expand the classroom, where possible, to make use of online classrooms through chat rooms, real time multimedia, and online access to labs.

\section{Information delivery}

- Use varied and simultaneous instructional strategies. Methods may include: student presentations, course readings, guest lecturers, active learning techniques, small group projects, activity sheets, take home or online exercises, videos, and group discussions.

- Ensure that course material is suitable for the course level.

- Make textbooks available in both print and digital format.

- Use jargon-free language and explain technical terminology.

- Give students regular breaks during class.

\section{Student evaluation}

- Use various assessment strategies and allow for choice of assignment format, whenever possible. 
- Use scaffolding techniques with practice exercises and constructive feedback.

- Employ a grading rubric or study guides, samples of expected work, and sample exams, and create a comprehensive syllabus with clear expectations.

\section{Faculty-student communication}

- Develop a course syllabus that clearly outlines the goals and expectations of the course.

- Provide regular and prompt feedback to students. Allow students to provide regular and anonymous feedback to you.

- Hold regular office hours and set clear email guidelines so students can discuss questions and concerns individually.

\section{Creating a community of learners}

- Create opportunities for students to interact with each other during class time.

- Encourage study groups, online discussion boards, chat rooms, in-class group discussions, and group assignments.

- Acquire available technology, equipment, and services to improve educational opportunities.

\section{Creating an inclusive environment}

- Allow students to develop their class code of conduct as a group.

- Develop a class syllabus that contains inclusive and respectful wording.

- Ensure rubrics reflect a respectful, inclusive approach.

Many of these strategies are familiar to high-quality instructors, and many committed instructors have discovered these effective teaching strategies as part of their personal journeys in becoming effective educators. The following section discusses recognizing, as well as developing, good teaching strategies as tools towards effective teaching.

\section{Discussion}

The learner-centred perspective, the Seven Principles for Good Practice in Undergraduate Education (Chickering \& Gamson, 1987), and UID principles reflect similar approaches as they aim to aid faculty in providing effective academic instruction for firstyear students. However, UID is the most useful in providing faculty effective teaching methods. The learning-centred approach lacks specific guidelines and principles, and Chickering and Gamson's Seven Principles lack guidelines that could be applicable in all instructional settings. The UID approach builds on the other two approaches by developing instructions to meet the needs of students rather than instructors. It also provides a set of principles that are broad enough to allow for the practical application of its methods to all areas of instruction.

Many instructors have informally discovered UID teaching strategies and find that they are effective in the classroom. Research on UID confirms their observations and formally recognizes these important practices (Burgstahler \& Cory, 2008). Faculty who practice effective teaching strategies should be encouraged to study UID principles and discover added ways to incorporate UID teaching strategies into their teaching.

Although certain faculty already use UID strategies, it is important to expose all instructors to these strategies and to encourage UID strategies to be applied uniformly within classrooms across all instructional areas. It is unlikely the sporadic application of UID principles within any particular university will result in increased first-year student retention. However, by applying these principles as the norm of instruction across the university, students as a whole are likely to achieve better academic results. They will also feel more positive about the university community, which in turn should lead to a greater retention of first-year students. Achieving the successful implementation of UID-based teaching strategies requires that faculty rethink perspectives on what it means to provide accessible education. Therefore, university administrations should aim to support implementing UID at their institutions by 
providing the facilities with technology and faculty training needed for the successful implementation of UID and its empirical support.

\section{References}

Blizzard, D. \& Foster, S. (2007). Feminist pedagogy and universal design in a deaf and hearing world: Linking cultures through artifacts and understanding. Feminist Teacher, 17(3), 225-236.

Burgstahler, S.E. (2008). Universal design of instruction: From principles to practice. In S.E. Burgstahler \& R.C. Cory (Eds.), Universal design in higher education: From principles to practice (pp.23-44). Cambridge, MA: Harvard Education Press.

Burgstahler, S.E. \& Cory, R.C. (Eds.). (2008). Universal design in higher education: From principles to practice. Cambridge, MA: Harvard Education Press.

Carter, I., Leslie, D., \& Moore, S. (2009, June). What teaching methods promote a successful transition to university? Developing a set of guidelines for first year course instructors. Paper presented at the $29^{\text {th }}$ annual conference of the Society for Teaching and Learning in Higher Education, University of New Brunswick, Fredericton, NB.

Chickering, A.W. \& Gamson, Z.F. (1987). Seven principles for good practice in undergraduate education. Retrieved from http://learningcommons.evergreen.edu/pdf/ fall1987.pdf

Coomber, S.A. (2007). Students with disabilities: Post-secondary voices and universal design for learning (Doctoral dissertation, Simon Fraser University). Retrieved from http://ir.lib.sfu.ca /handle/1892/3463

Embry. P.B., Parker, D.R., McGuire, J.M., \& Scott, S.S. (2005). Postsecondary disability service providers' perceptions about implementing Universal Design for Instruction (UDI). Journal of Postsecondary Education and Disability, 18(1), 34-48.

Galka, A. \& Gold, N. (2006). Neil Gold explains learning-centredness. ReFLEXions, 1(2). Retrieved from http://apps.medialab.uwindsor. $\mathrm{ca} / \mathrm{cfl} /$ reflexions/volume01/issue02/Gold2. htm

Finkel, G. \& Gold, Y. (1999). Actualizing universal design. Journal of Leisurability 26(1). Retrieved from http://lin.ca/Files/3745/sr022. pdf

Hebdon, H.M. (2007). Universal design: Making education accessible to all students. The Exceptional Parent, 37(5), 70.

Hubball, H., Gold, N., Mighty, J., \& Britnell, J. (2007). Supporting the implementation of externally generated learning outcomes and learning-centred curriculum development. New Directions for Teaching and Learning, 112, 93-105.

Mino, J.J. (2004). Planning for inclusion: Using universal instructional design to create a learnercentred community college classroom. Equity \& Excellence in Education, 37(2), 154-160.

Samuels, C.A. (2007). 'Universal Design' concept pushed for education. Education Week: American Education's Newspaper of Record, 27(10), $1-12$.

Scott, S. \& McGuire, J. (2008). A case study approach to promote practical application of universal design for instruction. In S.E. Burgstahler \& R.C. Cory (Eds.), Universal design in higher education: From principles to practice (pp.135-143). Cambridge, MA: Harvard Education Press.

Stolarchuk, L., Carter, I., \& Leslie, D. (2009, May). 
Examples of universal design in education $(U D E)$. Poster presented at the third annual University of Windsor and Oakland University Teaching and Learning Conference, University of Windsor, Windsor, ON.

Thousand, J.S., Villa, R.A., \& Nevin, A.I. (2002). Creativity and collaborative learning: The practical guide to empowering students, teachers, and families ( $2^{\text {nd }}$ ed.). Baltimore, MD, US: Paul H. Brookes Publishing.

Weimer, M. (2002). Learner-centered teaching: Five key changes to practice. San Francisco, CA: Jossey-Bass.

Yuval, L. \& Korabik, K. (2003). Measured outcomes of the universal instructional design project. University of Guelph: Department of Psychology. Retrieved from http://www.tss.uoguelph. $\mathrm{ca} /$ uid/uidsummary.cfm

\section{Biographies}

Irene Carter, Ph.D., is an Assistant Professor in School of Social Work, and Program Coordinator, Disability Studies, at the University of Windsor. Her main areas of interest are social support for people with developmental and intellectual disabilities, disability studies, and self-help groups.

Donald R. Leslie, Ph.D., is a Professor and Chair of the Undergraduate and Graduate Programs at the School of Social Work, at the University of Windsor. His research interests over the past 30 years have included disability studies, accommodation and accessibility for people with disabilities, program evaluation, and non-profit governance.

Sarah Moore is an MSW Candidate and research assistant at the University of Windsor. 